\title{
Estimating Earnings Losses of Migrant Workers Due to COVID-19
}

\author{
Manolo I. Abella ${ }^{1,2} \cdot$ S. K. Sasikumar ${ }^{3}$
}

Accepted: 2 September 2020 / Published online: 21 October 2020

(c) Indian Society of Labour Economics 2020

\begin{abstract}
While the wide-ranging impact of COVID-19 on incomes and livelihoods of people around the world will take some time to become known and understood, it is already clear that those who are in manual, mostly low-wage, occupations are among the worst-hit workers. This paper uses data from a sample survey of migrant workers to come up with useful parameters for estimating the potential losses from possible retrenchment of migrant workers due to the pandemic. The paper employs a simple estimation model using parameters derived from data collected from a KNOMADILO survey of low-skilled migrant workers in the India-Saudi Arabia migration corridor, conducted during 2016-2017. An important finding is that the aggregate losses that low-skilled Indian workers in Saudi Arabia are likely to incur due to COVID-19-related retrenchment may be as high as $21 \%$ of their expected earnings. Adding recruitment costs can push up their losses to $36 \%$ of expected or potential earnings, while the aggregate remittances to their families could drop by USD 2 billion.
\end{abstract}

Keywords COVID-19 · Labour migration · Earning loss of migrant workers · IndiaGulf migration $\cdot$ KNOMAD-ILO surveys

\section{Introduction}

It will be a while before the full impact of COVID-19 on incomes and livelihoods of people around the world becomes known and understood, but it is already obvious that those in manual, mostly low-wage, occupations are among the workers most adversely affected. They include not only those who, by the nature of their jobs, are

S. K. Sasikumar

sasikumarsk2@gmail.com

1 ILO International Migration Programme, Geneva, Switzerland

2 World Bank-KNOMAD Labour Migration, Washington, USA

3 V.V. Giri National Labour Institute, Noida, India 
more exposed to the virus than others, such as hospital and nursing home workers and public transport drivers, but also many others who are employed in industries that have suffered from the overall economic meltdown. These encompass a wide variety of occupations from itinerant vendors, store clerks and restaurant workers, to manufacturing workers, farmers and fishermen, traders and truckers, public sanitation workers and the like. In more economically advanced countries, a significant proportion of those employed in these occupations are foreign migrant workers who enjoy few rights, least of all to any job security, and are thus the most likely to have been the first to be laid off, to suffer pay cuts, or not to have been paid at all for previous work (Abella 2020; World Bank - KNOMAD 2020a). In the Gulf countries, these migrant workers make up most of those employed in the private sector and thus constitute the bulk of the total workforce.

This paper proposes, by way of example, a method for quantitatively assessing the likely impact of the economic crisis on migrant workers who are on temporary employment in countries hit by the pandemic. It employs a simple estimation model using parameters derived from data collected from a survey by the Global Knowledge Partnership on Migration and Development (World Bank - KNOMAD) and the International Labour Organization (ILO) of 409 low-skilled Indian workers who worked in Saudi Arabia, or were still working there in September 2016. ${ }^{1}$ The survey, one of 19 conducted in 2015 and 2016, was designed to measure migration costs incurred by the migrant workers. It obtained information on, among others, when they started working and for how much longer they expected to work abroad, how much in wages they were offered and how much they actually earned, how much they paid recruiters, brokers and others, and what they paid for fees and other expenses related to their migration, whether they borrowed money, mortgaged properties and how much they paid in interest, how much they remitted home to their families, and under what conditions they worked. ${ }^{2}$

\footnotetext{
1 The respondents for the survey were drawn from Indian migrant workers arriving from Saudi Arabia at Delhi airport from September 2016 to January 2017.

2 KNOMAD-ILO Migration and Recruitment Cost Surveys on migration costs-https://www.knoma d.org/data/recruitment-costs_conducted in 2015 and 2016, covered over 19 bilateral migration corridors with a total of 5603 interviewed migrants. The migration corridors were:
}

- India to Saudi Arabia

- India to Qatar

- Philippines to Qatar

- Vietnam to Malaysia

- Guatemala, Honduras and El Salvador to Mexico (non-recruited workers)

- Philippines to Saudi Arabia

- Pakistan to Saudi Arabia

- Pakistan to United Arab Emirates

- Ethiopia to Saudi Arabia

- Nepal to Qatar

- Nepal to Malaysia

- Nepal to Saudi Arabia

- Kyrgyzstan, Tajikistan, Uzbekistan to Russia (non-recruited workers)

- West African countries to Italy (non-recruited workers). 


\section{Impact of COVID-19 on Employment of Migrant Workers in Saudi Arabia}

Saudi Arabia has emerged as the main destination for Indian migrant workers, especially among the low-skilled, over the past four decades. Government of India records on emigration clearances show that those issued for workers going to Saudi Arabia represented nearly $40 \%$ of all clearances issued during the last two decades (Table 6 in "Appendix"). ${ }^{3}$ In 2019, it was estimated that there were 2.44 million Indian migrants in Saudi Arabia (Table 7 in "Appendix").

There is a very strong relationship between economic growth in Gulf Cooperation Council (GCC) countries and emigration of workers from India. Figure 1 shows the growth rates of gross domestic product (GDP) in the GCC countries and the emigration clearances granted by the Indian government. They reveal a clear relationship, albeit with a time lag. The decline in the number of emigration clearances granted followed the deceleration of economic growth in all the six GCC countries over the past decade.

Since the pandemic is still on the rise, it is not possible to say how many Indian migrant workers will keep their jobs, and for how long, and whether those who keep their jobs will suffer from cuts in their wages. Oil represents $80 \%$ of Saudi Arabia's exports and contributes $70 \%$ of government revenues. The World Bank forecasts that the price of oil per barrel will hover around USD 33.4 per barrel in 2020, about $48 \%$ lower than its average price in 2019, which will inevitably impact Saudi Arabia's economy (World Bank 2020b). IMF forecasts that Saudi Arabia's GDP will decline by $2.3 \%$ in 2020 (IMF 2020).

Such a huge drop in oil prices is bound to severely squeeze Saudi Arabia's public finances and many new as well as ongoing projects are already being put on hold. The impact of these changes on employment across the board is still unfolding, but it is already clear that some of the sectors where Indian migrant workers are concentrated, such as construction, tourism and oil drilling, have been badly affected. Aviation, travel and tourism, and hospitality, major drivers of the GCC, have been decimated because of travel, transport and border restrictions (ILO 2020). Recreational activities, hospitality, and wholesale and retail trade were quickly shut down as government restrictions targeted crowd-oriented businesses. Services, which employs over $70 \%$ of the labour force, have largely been driven by tourism which in turn depends heavily on the pilgrimage to Mecca. By the middle of 2020, it was reported that some 323,000 foreign workers had already been sent home from Saudi Arabia (Nereim 2020).

In May 2020, India launched an emergency evacuation programme (Vande Bharat Mission) to airlift home those in distress, including migrant workers who have been laid off, short-term visa holders faced with expiry of visas, persons with medical emergency, elderly persons, pregnant women, those who require to return to India due to the death of a family member, and students. Migrant workers evacuated from

\footnotetext{
${ }^{3}$ Emigration clearances are required for Indians with educational attainment below matriculate who are migrating for employment to 18 countries. Nearly $95 \%$ of the emigration clearances are granted to those migrating to GCC countries.
} 


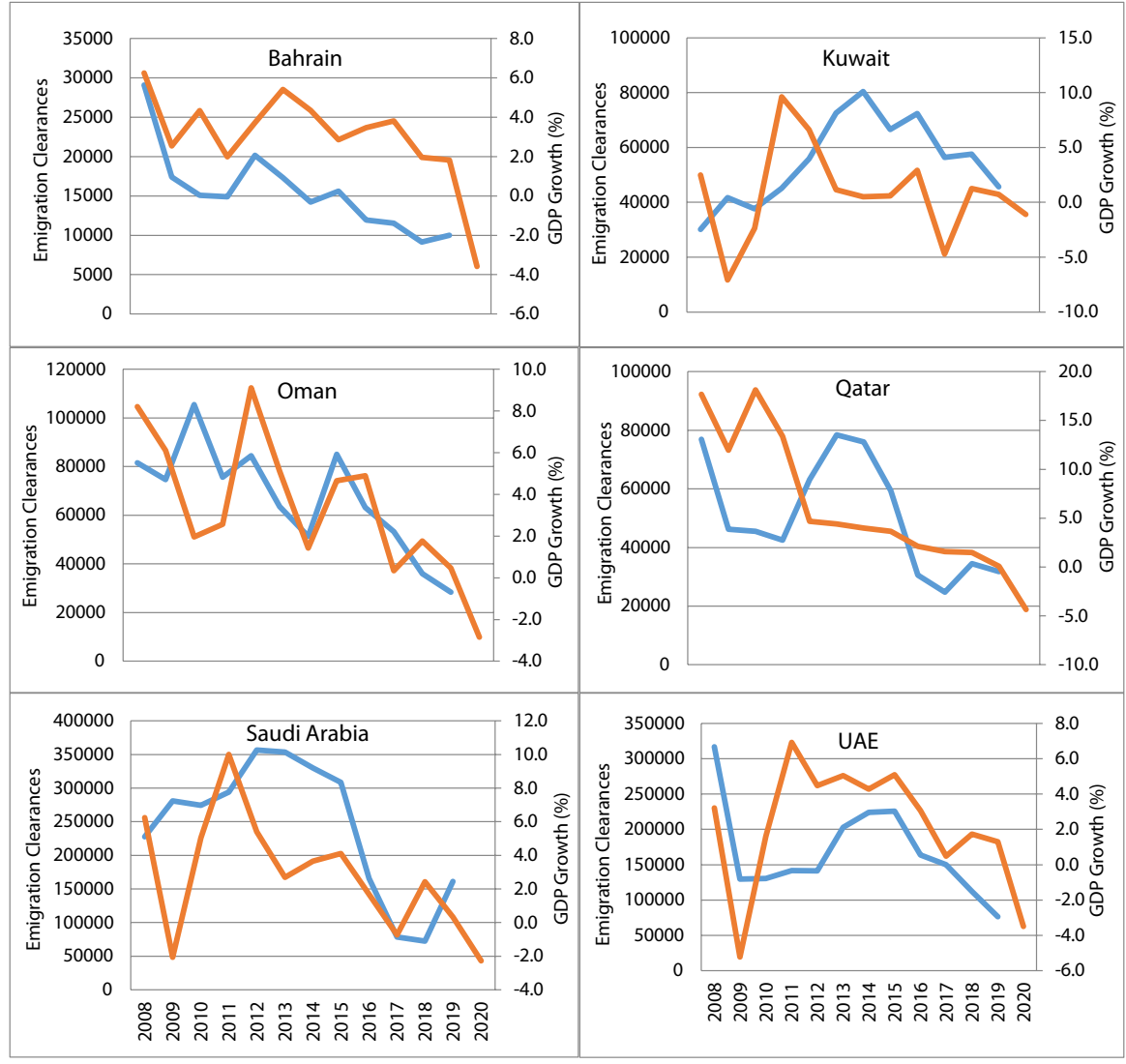

- Emigration clearances —GDP growth (\%)

Fig. 1 Emigration from India and GDP Growth of GCC Countries. Source: IMF, World Economic Outlook (various years) for GDP growth rates; and $e$ Migrate, Ministry of External Affairs, Government of India, for emigration clearances

GCC countries are required to bear the cost of USD 300-350 which cover airfare plus the cost for institutional quarantine. Understandably, those who do not have adequate money to meet these costs decide to stay on in the Gulf countries. By end of July 2020, nearly 600,000 Indians were reported to have returned to India from different countries under the Vande Bharat Mission, and among them less than a third (150,000-180,000), were migrant workers (Ministry of External Affairs, Media Briefings).

\section{Estimating the Impact of COVID-19 on Indian Migrant Workers}

Simply counting the number of workers returning from abroad to assess the impact of the pandemic is not very satisfying since it reveals little about the actual degree of economic distress they suffer when they lose their jobs. Some return because they 
have managed to complete their employment contracts abroad. These would be far better off than those workers who are just starting their employment but are laid off and have no choice but return. What about those who are now settling for less than was promised because they still have hopes of recovering their investment once the pandemic-related economic crisis is over? Those who paid large amounts of money for their recruitment and those who went into debt in order to finance their migration will surely be worse off than those who were hired directly by their employers. It is not clear whether those who lose high-paying jobs will be worse off than those who are earning less, but it is clear that a simple count of dislocated workers gives a very incomplete picture. One may also have to take into account the size of families they support, their age, their previous earnings at home, and the number of times they have been abroad, to have a fuller understanding of how this crisis is affecting migrant workers and their families.

This paper proposes a simple methodology for taking into account some of these dimensions of possible distress. Detailed data on employment contracts of Indian workers granted clearance to migrate should be available but are unfortunately not reported or released by the Indian government. Had these been available, it would have been possible to estimate potential earnings losses of all the workers from the information about their contractual wages, lengths of their contracts, and at least the month of the year when they left.

In the quest for a good alternative, this paper draws on the findings of the KNOMAD-ILO survey on migration costs referred to earlier. This survey is of 409 lowskilled Indian workers returning from Saudi Arabia in late September 2016 to early 2017. The survey provides sufficient data to estimate the extent of potential losses of migrant workers who may not be able to complete their contracts. The following simple estimation model was used for the purpose:

Let $w_{i}$ be the monthly wage of migrant worker $i$, where $i$ goes from 1 to $n$.

Let $m_{i}$ be the length of the contract of migrant worker $i$ in months.

Then $\sum_{i=1}^{n} w_{i} m_{i}$ is the sum of the expected earnings from all migrant workers for the duration of their contracts.

Now, let $l_{i}$ be the number of months remaining in the contract of migrant worker $i$, which he or she will not be able to complete because of retrenchment caused by the COVID-19 crisis. For migrant workers not retrenched, $l_{i}=0$.

Then $\sum_{i=1}^{n} w_{i} l_{i}$ is the expected sum of lost earnings from migrant workers who will be retrenched, and $\sum_{i=1}^{n} w_{i}\left(m_{i}-l_{i}\right)$ is the expected sum of earnings from all migrant workers after taking retrenchments into account.

The share of potential migrant earnings lost because of the COVID-19 crisis is given by $p$ :

$$
\frac{\sum_{i=1}^{n} w_{i} l_{i}}{\sum_{i=1}^{n} w_{i} m_{i}}=p
$$

The KNOMAD-ILO survey found that practically all the respondents were on two-year employment contracts. If it can be assumed that all the low-skilled Indian 
migrant workers who left for Saudi Arabia over the past 2 years were also on 2-year contracts, then the estimate of $p$ should be a good parameter for the share of potential earnings loss of India's current migrant workforce in that country.

Since the KNOMAD-ILO survey collected information on how much the migrants remitted home periodically to their families, it is also possible to estimate a parameter that can be used to estimate the amount of remittances that may be lost if workers are laid off, or if their wages were reduced. For that parameter:

Let $r_{i}$ be the portion of migrant worker $i$ 's earnings sent home as remittances.

Then $\sum_{i=1}^{n} r_{i} w_{i} l_{i}$ is the expected sum of remittances lost due to retrenchments. The estimate of the share of remittances lost because of the COVID-19 crisis would thus be given by:

$$
\frac{\sum_{i=1}^{n} r_{i} w_{i} l_{i}}{\sum_{i=1}^{n} r_{i} w_{i} m_{i}}=d
$$

One may speculate what would happen to $d$ if $w_{1} l_{1}$ were to decrease because for the remaining months in the contract, employers are only willing to keep workers in employment at a lower wage. Some studies of remittance-sending behaviour of migrants suggest that they may actually raise the portion of earnings sent home to $r_{\mathrm{p}}^{\prime}$ so as to maintain the same or similar level of remittances to their families (BouhgaHagbe 2006).

In the absence of relevant information, one can only postulate likely scenarios of how wages will be affected. For example, a 30\% drop in average wages for each worker $i$ for the same period $l_{1}$ can be postulated so that:

$$
w_{I}^{\prime}=0.70 w_{i}
$$

The estimate of the adjusted share of remittances lost will then be given by:

$$
\frac{\sum_{i=1}^{n} r_{i}^{\prime} w_{i}^{\prime} l_{i}}{\sum_{i=1}^{n} r_{i} w_{i} m_{i}}=d^{\prime}
$$

It is of course likely that not only will $w$ and $r$ change but also $l$, since if the workers agree to a lower wage, the number of months they are not able to complete in their contract will change as well (it will reduce or even become zero). In this scenario, the share of remittances lost is probably better denoted by:

$$
\frac{\sum_{i=1}^{n}\left(r_{i} w_{i}-r_{i}^{\prime} w_{i}^{\prime}\right) m_{i}+r_{i}^{\prime} w_{i}^{\prime} l_{i}^{\prime}}{\sum_{i=1}^{n} r_{i} w_{i} m_{i}}=d^{\prime \prime}
$$

This was derived as follows:

$\sum_{i=1}^{n} r_{i}^{\prime} w_{i}^{\prime}\left(m_{i-} l_{i}^{\prime}\right)=$ total remittances after wage adjustments, retrenchments (taking into account wage adjustments), and adjustments in share of wages remitted. 
$\sum_{i=1}^{n} r_{i} w_{i} m_{i}-\sum_{i=1}^{n} r_{i}^{\prime} w_{i}^{\prime}\left(m_{i-} l_{i}^{\prime}\right)=$ total remittances foregone or lost due to wage adjustments, retrenchments (taking into account wage adjustments), and adjustments in share of wages remitted.

After the requisite calculations and subsequently dividing the figure obtained by the total expected remittances pre-COVID-19, we get a measure of the share of potential remittance loss after taking into account possible wage decrease and change in propensity to remit ${ }^{4}$ :

$$
\frac{\sum_{i=1}^{n}\left(r_{i} w_{i}-r_{i}^{\prime} w_{i}^{\prime}\right) m_{i}+r_{i}^{\prime} w_{i}^{\prime} l_{i}^{\prime}}{\sum_{i=1}^{n} r_{i} w_{i} m_{i}}
$$

Most of the migrants had to pay brokers and recruitment agencies hefty amounts to get their jobs. The KNOMAD-ILO survey found that Indian migrant workers who found work in Saudi Arabia incurred recruitment costs that were equivalent, on average, to 3.5 months of wages in Saudi Arabia. Those who were able to work only these many months before they get laid off on account of the crisis would obviously be in dire straits.

What the worker spent to get employment abroad is in a real sense an actual loss for the worker regardless of how much he or she is able to earn abroad. Even if the recruiter pays back all or some of the recruitment service fees, the worker will not be able to recover some of the sunk costs such as for airfare, medical check-up, passport fees and related expenses. Thus, if he or she is not able to work and earn money abroad the total cost of recruitment can be treated as an 'actual' cost in addition to the 'potential loss' of income if he or she suffers from pre-mature lay-off or wage deduction.

If recruitment cost is $c_{\mathrm{i}}$ then the share of the actual + potential loss out of total anticipated income will simply be:

$$
\frac{\sum_{i=1}^{n} w_{i} l_{i}+c_{i}}{\sum_{i=1}^{n} w_{i} m_{i}}
$$

\section{KNOMAD-ILO Sample for the India-Saudi Arabia Migration Corridor}

The survey was carried out in two overlapping stages. The first stage of the survey involved interviewing migrant workers returning from Saudi Arabia to India to generate a broad profile. The respondents included both current emigrants

\footnotetext{
${ }^{4}$ This was derived as follows:

$\sum_{i=1}^{n} r_{i}^{\prime} w_{i}^{\prime}\left(m_{i-} l_{i}^{\prime}\right)=$ total remittances after wage adjustments, retrenchments (taking into account wage adjustments), and adjustments in share of wages remitted

$\sum_{i=1}^{n} r_{i} w_{i} m_{i}-\sum_{i=1}^{n} r_{i}^{\prime} w_{i}^{\prime}\left(m_{i-} l_{i}^{\prime}\right)=$ total remittances foregone or lost due to wage adjustments, retrenchments (taking into account wage adjustments), and adjustments in share of wages remitted.
} 
(those travelling to India on vacation who would return to Saudi Arabia within a short time) and return migrants (those returning after completing their contractual period). The purpose was to obtain basic information about the migrants to select a representative sample. Information was obtained on: contact details including age and origin state; year of last migration and occupation; whether current or return migrant; and willingness to be part of the survey. Following the KNOMAD-ILO guidelines, the sample was restricted to low-skilled workers whose most recent contract of employment was dated not earlier than 2011 and not later than 2015. For the India survey, it was further decided to narrow the sample to low-skilled construction workers. It is important to note that a significant proportion of low-skilled migrant workers in the GCC countries are engaged in the construction sector. For instance, in Saudi Arabia, 44\% of the migrant workers in the private sector were employed in the construction sector in 2018 (De Bel-Air 2018).

A fair representation of the geographical origin of the migrants was used as one of the criteria for choice of respondents because the overwhelming bulk of migrants to Saudi Arabia since the 2000s, and especially since 2008, have been from North India (Uttar Pradesh, Bihar, Punjab, Rajasthan, Jharkhand and Haryana). The choice of Delhi airport was because it has been the most important arrival point for workers coming back from Saudi Arabia. A total of 439 total respondents were interviewed, of which 30 were rejected because of insufficient or incomplete information.

The survey found that about 1 in 5 of the respondents had worked abroad more than once while the rest were first-time migrants (Table 1). An overwhelming proportion of the migrants (88\%) were from the prime age groups 25-39 while 9\% were above 40 years, quite typical of the circular migration pattern of Indian labour to the Gulf. More than 93\% were married. Again quite characteristically for low-skilled labour, more than half the sample was either illiterate or with education up to the primary level $(56 \%)$. Given that the sample was drawn exclusively from low-skilled migrants with emigration clearance requirement-which necessarily meant below matriculation-it is still indicative of the extremely skewed nature of skill and education levels of the migrants that more than half were illiterate or barely literate.

Prior to leaving for Saudi Arabia, an overwhelming majority of the migrants were in informal employment, primarily in sectors such as construction, low-end services, small manufacturing and agriculture. They earned on average USD 162 a month in India before they left but doubled this to USD 325 on their first month in Saudi Arabia. However, the survey revealed that they incurred very high migration costs, equivalent to at least 5 months of their initial earning abroad. With interest rates added, it took some migrants who borrowed money more months of their earnings abroad to recover their investment in migration.

As to their mode of recruitment, an overwhelming number of respondents seemed to have been recruited by individual agents or what is known to be an extensive network of subagents and visa brokers who ultimately channel the labour flow through the licensed agencies (Table 2).

Table 3 shows that almost all (98.7\%) of the sample respondents arrived in Saudi Arabia not earlier than 2 years before the survey was conducted. The few who arrived earlier probably had their contracts extended. 
Table 1 Characteristics of sample

\begin{tabular}{ll}
\hline Characteristics & Total \\
\hline State of origin & \\
Bihar & $182(44.5)$ \\
Uttar Pradesh & $148(36.19)$ \\
Others & $79(19.32)$ \\
Age group & \\
20-24 & 2.20 \\
25-29 & 23.96 \\
30-34 & 40.59 \\
35-39 & 23.96 \\
40 and above & 9.29 \\
Marital status & \\
Married & 93.40 \\
Single & 6.60 \\
Level of education & \\
None & 6.11 \\
Primary & 50.61 \\
Secondary & 42.54 \\
Post-secondary & 0.73 \\
Frequency of migration & \\
More than once & \\
First time & 18.58 \\
& 81.42 \\
\hline
\end{tabular}

Source: KNOMAD-ILO Survey on Migration Cost, India-Saudi Arabia Corridor, 2016-2017

However, almost half of the migrant respondents were returning for good, indicating that they started working sometime in 2014. About half of the rest still had 4 months or more to fulfil in their contracts (Table 4). This distribution is expected because it is well known that 2 years is the most common length of job contracts for low-skilled workers in Saudi Arabia and other GCC countries.

The workers were promised wages which, on average, conformed to the Government of India fixed minimum referral wages ${ }^{5}$ for various occupations prevailing as on May 2016 (see Table 8 in "Appendix").

Table 5 shows that the survey respondents earned considerably less even with overtime work. Their most recent reported earnings were only $82 \%$ of the wage they were promised. They remitted about $60 \%$ of these earnings, on average, to their families.

\footnotetext{
${ }^{5}$ In recent years, the Government of India has been fixing minimum referral wages to regulate the wages of Indian migrant workers employed in different countries who fall under the emigration clearance requirement. For a detailed discussion of the functioning of the minimum wage referral system in the context of migration flows in the India-GCC corridor, see Sasikumar and Sharma (2016).
} 
Table 2 Sample distribution by mode of recruitment

\begin{tabular}{|c|c|c|c|c|}
\hline Indicator & Individual broker & $\begin{array}{l}\text { Recruitment } \\
\text { agency }\end{array}$ & Relatives/friends & Total \\
\hline \multicolumn{5}{|l|}{ State of origin } \\
\hline Bihar & 80.66 & 2.21 & 17.13 & 100.00 \\
\hline Uttar Pradesh & 79.05 & 2.70 & 18.24 & 100.00 \\
\hline Others & 78.21 & 1.28 & 20.51 & 100.00 \\
\hline \multicolumn{5}{|l|}{ Age group } \\
\hline $20-24$ & 66.67 & 0.00 & 33.33 & 100.00 \\
\hline $25-29$ & 82.65 & 1.02 & 16.33 & 100.00 \\
\hline $30-34$ & 80.00 & 1.82 & 18.18 & 100.00 \\
\hline $35-39$ & 80.41 & 2.06 & 17.53 & 100.00 \\
\hline 40 and above & 71.05 & 7.89 & 21.05 & 100.00 \\
\hline \multicolumn{5}{|l|}{ Marital status } \\
\hline Married & 80.79 & 2.11 & 17.11 & 100.00 \\
\hline Single & 62.96 & 3.70 & 33.33 & 100.00 \\
\hline \multicolumn{5}{|l|}{ Level of education } \\
\hline None & 83.33 & 0.00 & 16.67 & 100.00 \\
\hline Primary & 75.85 & 1.93 & 22.22 & 100.00 \\
\hline Secondary & 83.82 & 2.31 & 13.87 & 100.00 \\
\hline Post-secondary & 66.67 & 33.33 & 0.00 & 100.00 \\
\hline Total (in \%) & 79.61 & 2.21 & 18.18 & $100.00(N=409)$ \\
\hline
\end{tabular}

Source: KNOMAD-ILO Survey on Migration Cost, India-Saudi Arabia Corridor, 2016-2017

Table 3 Sample distribution by year of arrival in Saudi Arabia and months already worked

\begin{tabular}{|c|c|c|c|c|c|c|c|c|c|c|c|c|}
\hline \multirow[t]{2}{*}{ Year arrived } & \multicolumn{11}{|c|}{ Months already worked in Saudi Arabia } & \multirow[t]{2}{*}{ Grand total } \\
\hline & 10 & 11 & 13 & 14 & 15 & 16 & 17 & 20 & 24 & 32 & 48 & \\
\hline 2012 & & & & & & & & & & & 4 & 4 \\
\hline 2013 & & & & & & & & & & 1 & & 1 \\
\hline 2014 & & & 1 & 1 & & 1 & & & 201 & & & 204 \\
\hline 2015 & 10 & 7 & 55 & 92 & 19 & 15 & 1 & 1 & & & & 200 \\
\hline Grand total & 10 & 7 & 56 & 93 & 19 & 16 & 1 & 1 & 201 & 1 & 4 & 409 \\
\hline Percent share & 2.4 & 1.7 & 13.7 & 22.7 & 4.6 & 3.9 & 0.2 & 0.2 & 49.1 & 0.2 & 1.0 & 100 \\
\hline
\end{tabular}

Source: KNOMAD-ILO Survey on Migration Cost, India-Saudi Arabia Corridor, 2016-2017

\section{Estimated Parameters}

Drawing on the data from the KNOMAD-ILO survey, parameters were calculated to approximate the likely impact of the pandemic-created crisis on Indian migrant workers in Saudi Arabia. In particular, the paper sought to estimate the extent of 
Table 4 Sample distribution by year of arrival in Saudi Arabia and months more of expected stay

\begin{tabular}{|c|c|c|c|c|c|c|c|c|c|c|c|c|c|}
\hline \multirow[t]{2}{*}{ Year arrived } & \multicolumn{12}{|c|}{ Months more of expected stay, by arrival year } & \multirow[t]{2}{*}{ Grand tota } \\
\hline & 0 & 3 & 4 & 7 & 8 & 9 & 10 & 11 & 12 & 13 & 14 & 16 & \\
\hline 2012 & 4 & & & & & & & & & & & & 4 \\
\hline 2013 & & & & & & & & & & & & 1 & 1 \\
\hline 2014 & 194 & 2 & 5 & & 1 & & 1 & 1 & & & & & 204 \\
\hline 2015 & & & 1 & 1 & 15 & 19 & 92 & 55 & 1 & 7 & 9 & & 200 \\
\hline Grand total & 198 & 2 & 6 & 1 & 16 & 19 & 93 & 56 & 1 & 7 & 9 & 1 & 409 \\
\hline Percent share & 48.4 & 0.5 & 1.5 & 0.2 & 3.9 & 4.6 & 22.7 & 13.7 & 0.2 & 1.7 & 2.2 & 0.2 & 100 \\
\hline
\end{tabular}

Source: KNOMAD-ILO Survey on Migration Cost, India-Saudi Arabia Corridor, 2016-2017

the loss in terms of foregone earnings and the effect on remittances under various scenarios.

(a) Potential earnings loss:

If all the migrant workers are laid off without completing their contracts the share of potential migrant earnings lost, $p$, because of COVID-19 is:

$$
p=0.211
$$

Thus, over one-fifth of the total expected earnings of all Indian migrants in Saudi Arabia would likely be lost if they were laid off, say, at the start of the pandemic and subsequent lockdown. It may be noted that this is what might be considered the upper bound of any estimated loss.

\section{(b) Potential remittances loss:}

The share of remittances lost, assuming no change in the original contracted wage of the migrant, $w_{1}$, and no change in the proportion of wage he or she usually remitted in the past, $r_{l}$, is estimated as:

$$
d=0.17
$$

As explained earlier, these statistics were estimated from a survey of low-skilled Indian construction workers. The extent to which these would be applicable for estimating the potential losses of the entire Indian workforce in Saudi Arabia would depend on how representative the sample is of their skill composition, and of their usual length of contractual engagements. Those who have longer than two-year contracts stand to suffer a bigger loss than those with shorter ones. At the same time, those with higher skills, presumably the more scarce skills, may not be in as acute a danger of being laid off as the less skilled. It is well known that many highly skilled Indians have gone to work in the GCC countries and they are likely to have longer term contracts than construction labour. 


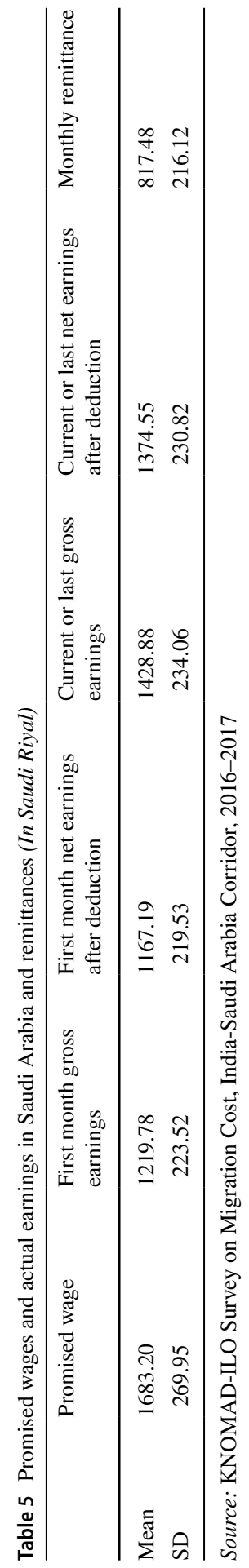


It is estimated that there were 2.44 million Indian migrant workers in Saudi Arabia in 2019 (UNDESA 2019), but information on their distribution by skill or length of their contracts is needed to refine the estimates. In 2018, India received an estimated USD 11.67 billion in remittances from Saudi Arabia (Table 9 in "Appendix"). Close to USD 2 billion in potential remittances may thus not materialise if all the workers lose their jobs in that country.

(c) Potential losses if workers stay but wages are lowered:

Let us now assume that all the workers are allowed to stay and complete their contracts $\left(l_{i}\right)$ but only at $30 \%$ lower wage, $w_{i}{ }^{\prime}$. In order to support their families back home at the same level as before, these workers would have to remit a higher proportion of their wages than before. For illustration, we assume that they would remit $10 \%$ more of their wages so that our new $r_{\mathrm{i}}=1.1 r_{i}{ }^{\prime}$. Equation (Please check and confirm the keywords are correctly identified.4) is used to estimate how much a loss it will be as a proportion of the original remittance level:

$$
\frac{\sum_{i=1}^{n}\left(r_{i} w_{i}-r_{i}^{\prime} w_{i}^{\prime}\right) m_{i}+r_{i}^{\prime} w_{i}^{\prime} l_{i}^{\prime}}{\sum_{i=1}^{n} r_{i} w_{i} m_{i}}=d^{\prime \prime}
$$

Based on the sample data, if workers are not retrenched $\left(l_{i}^{\prime}=0\right)$ but their wages are cut by $30 \%$, and so as not to unduly set back their family incomes the workers remit $10 \%$ more of their wages, we estimate that the percentage drop in total potential remittances will be:

$$
d^{\prime \prime}=0.23 \text {. }
$$

(d) Factoring recruitment costs into workers' losses:

As argued, the expenses that migrant workers incur in order to get their jobs abroad, what is commonly referred to as recruitment costs, are in a real sense "sunk" costs that dislocate the worker regardless of how long he or she is able to work abroad. With an average recruitment cost of USD 1334 according to the KNOMAD-ILO survey, it takes a worker receiving an average of USD 376 a month in Saudi Arabia 3.5 months to recoup his or her investment. For the workers who are retrenched and unable to complete their contracts $\left(l_{\mathrm{i}}>0\right)$, the potential loss of earnings together with the recruitment costs $\left(c_{\mathrm{i}}\right)$ can be estimated, as a share of total potential earnings before the pandemic struck, thus:

$$
\frac{\sum_{i=1}^{n} w_{i} l_{i}+c_{i}}{\sum_{i=1}^{n} w_{i} m_{i}}=0.36
$$

In the foregoing analysis, the paper has attempted to illustrate how one can come up with insightful parameters on the likely impact of the pandemic-induced economic crisis on migrant workers' earnings. With better information, it should 
be possible to make more realistic assumptions about levels of retrenchments and changes in wages, as well as changes in remittance behaviour as migrants adjust to the new situation.

\section{Anticipating Changes in Migration}

The economies of the GCC countries have been devastated by the dual shocks of the oil price collapse and the outbreak and spread of COVID-19. Currently, the priority is to deal with the challenges in health infrastructure and also strengthen steps to arrest the spread of the virus. Efforts to revitalise different economic activities and rejuvenate the economies will receive more attention once the spread of the pandemic is halted.

It is quite certain that the post-crisis economic revival measures will also witness more vigorous adoption of measures for reducing the region's dependence on migrant workers. This is a policy that has been pursued in the GCC countries for more than three decades but with limited success. The current crisis and the rise in unemployment rates among the local labour will provide a strong case for more stringent measures to be implemented to reduce the dependence on migrant workers.

However, given the low human capital base of the region and the reluctance of local labour to engage in low-skilled occupations, it is quite likely that the dependence on migrant workers cannot be drastically reduced in the short to medium term. It is quite probable that the GCC countries, as a part of their economic diversification drive, will become more 'skill selective' and 'sector selective' with regard to the deployment of the migrant workers.

What is the situation in India, the most prominent migrant-sending country to the GCC region? The unemployment situation in India is worsening. As per the latest data, the unemployment rate in India has surged from $7.34 \%$ in July 2019 to $10.99 \%$ in July 2020, one of the highest rates in the history of independent India (CMIE 2020). The unemployment rate is alarming in some of the states which send a large number of workers to the Gulf: Kerala (20.1\%); Bihar (19.5\%); Tamil Nadu (13.5\%) and Uttar Pradesh (9.6\%). Existing research clearly highlights that migration to the Gulf has acted as a major safety valve to tackle unemployment in several states in India (Sasikumar 2014). The return of the distressed migrants from GCC countries due to job loss is bound to reverse this trend.

How does the future look in terms of low-skilled migration flows from India to the GCC countries and what are some of the key policy imperatives related to such possibilities?

As discussed earlier, although there will be a squeeze in the demand for migrant labour in the GCC countries, the region will continue its dependence on migrant workers in the short to medium term. The worsening unemployment situation in India will force potential low-skilled migrants to compete for the limited employment opportunities in the Gulf countries. This can push up migration costs as the private recruiting agencies will prefer to recruit those ready to pay higher agency fees. Anticipating such a situation, strong interventions to reduce or even eliminate 
recruitment costs charged by recruiting agents must become an immediate policy priority.

Such a policy priority assumes added significance in the context of Sustainable Development Goal 10.7, which calls on countries to facilitate orderly, safe, regular and responsible migration and mobility of people, including through the implementation of planned and well-managed migration policies. This goal includes the indicator 10.7.1: 'Recruitment cost borne by an employee as a proportion of monthly income earned in country of destination'. Our estimates of potential losses of Indian workers due to these costs highlight the significance of this goal.

The GCC countries are in the midst of diversifying their economies to respond to the collapsing oil prices and the post-pandemic recovery measures are expected to accelerate this process. This will obviously transform the emerging economic structure and also change the demand pattern for skills. Major labour-sending countries like India should continuously monitor these structural changes and assess how these affect the requirement for skills in order to evolve appropriate responses, such as imparting customised skill training to potential migrant workers in selected industrial training and skill development centres, and forging skill supply agreements with the GCC countries.

\section{Conclusion}

This paper seeks to demonstrate how one can use data from a sample survey of migrant workers to come up with useful parameters for estimating the potential losses from feared retrenchments of migrant workers. This follows the widely used convention of relying on small samples to estimate larger macro impacts. The KNOMAD-ILO surveys, now completed for 19 major migration corridors, are a gold mine for data on the personal profiles of low-skilled migrants, how much it costs workers to migrate, how much they earned at home and abroad, how much they remitted to their families, and conditions under which they are employed.

The paper demonstrated how it is possible, with the use of the sample data from the India-Saudi Arabia migration corridor, to derive parameters which can provide rich insights into the larger macro impact of the recent pandemic. This exercise found that potential losses are heaviest when the recruitment costs that migrants incur to get their jobs are factored in. Losses are likely higher the higher the wages and the longer the uncompleted contracts that workers signed up for. As expected, the magnitude of remittances depends not only on wage levels and how much longer the migrants can work but also on their propensity to remit earnings to their families.

Acknowledgements We acknowledge with thanks helpful suggestions and comments from Geoffrey Ducanes, Vinoj Abraham and Rimli Borooah.

\section{Appendix}

See Tables 6, 7, 8 and 9. 


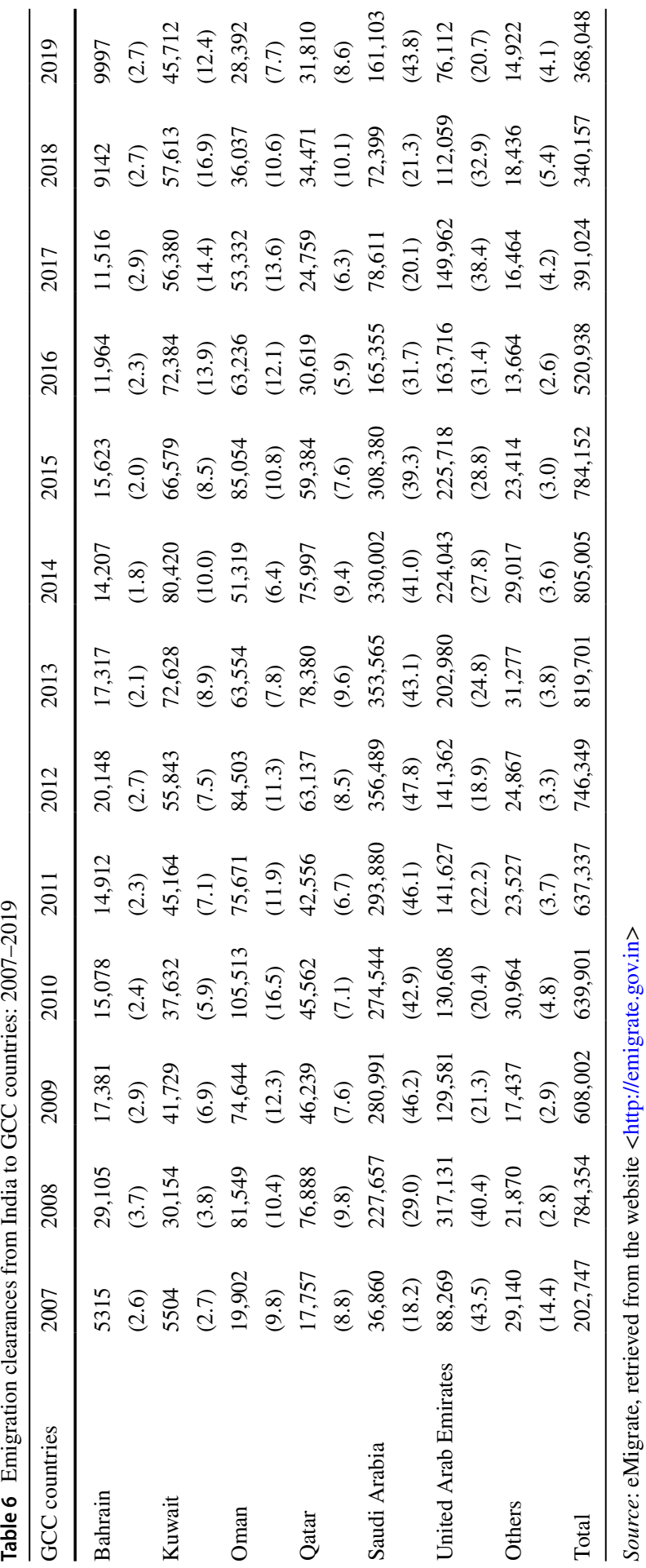


Table 7 Stock of Indian migrants in Gulf Cooperation Council Countries, 2019

\begin{tabular}{lllll}
\hline Country & Male & Female & Total & Total migrant stock in GCC countries \\
\hline Bahrain & 240,276 & 78,271 & 318,547 & 741,161 \\
& $(44.9)$ & $(38.1)$ & $(43.0)$ & \\
Kuwait & 792,611 & 331,645 & 1124,256 & $3,034,845$ \\
& $(39.4)$ & $(32.5)$ & $(37.0)$ & \\
Oman & $1,160,663$ & 164,781 & $1,325,444$ & $2,286,226$ \\
& $(60.7)$ & $(44.0)$ & $(58.0)$ & \\
Qatar & 600,826 & 97,262 & 698,088 & $2,229,688$ \\
& $(32.6)$ & $(25.3)$ & $(31.3)$ & \\
Saudi Arabia & $1,697,032$ & 743,457 & $2,440,489$ & $13,122,338$ \\
& $(18.9)$ & $(18.0)$ & $(18.6)$ & \\
United Arab Emirates & $2,626,998$ & 792,877 & $3,419,875$ & $8,587,256$ \\
& $(41.5)$ & $(35.1)$ & $(39.8)$ & \\
Total & $7,118,406$ & $2,208,293$ & $9,326,699$ & $30,001,514$ \\
\hline
\end{tabular}

Source: UNDESA, 2019

Table 8 Referral wages for Indian migrants in Saudi Arabia [as on May 2016, in Saudi Riyal)]

\begin{tabular}{|c|c|c|c|c|c|}
\hline \multicolumn{2}{|l|}{ Low-skilled workers } & \multicolumn{2}{|c|}{ Semi-skilled workers } & \multicolumn{2}{|l|}{ Skilled workers } \\
\hline Categories & Wages & Categories & Wages & Categories & Wages \\
\hline Ordinary Labour & 1500 & Decorator & 1700 & Nurse $(\mathrm{M} / \mathrm{F})$ & 2100 \\
\hline General Labour & 1500 & Auto Electrician & 1700 & Lab Technician & 2100 \\
\hline Construction Labour & 1500 & Tailor & 1700 & X-Ray Technician & 2100 \\
\hline Cleaning Labour & 1500 & Female Tailor & 1700 & Clerk/Typist & 2100 \\
\hline Fisherman & 1700 & $\begin{array}{l}\text { Heavy Equipment } \\
\text { Operator }\end{array}$ & 1900 & Secretary & 2100 \\
\hline All Kinds of Helpers & 1500 & Mason & 1700 & Accountant & 2500 \\
\hline Housemaid & 1500 & Cook & 1700 & Computer Operator & 2500 \\
\hline $\begin{array}{l}\text { Domestic Helper (Male } \\
\text { Servant) }\end{array}$ & 1500 & Carpenter & 1700 & Draftsman & 2500 \\
\hline Agriculture Labour & 1500 & Waiter & 1700 & Computer Programmer & 3500 \\
\hline Gardener & 1500 & Electrician & 1700 & & \\
\hline \multirow[t]{12}{*}{ Tile Fixer } & 1700 & Steward & 1700 & & \\
\hline & & Steel Fixer & 1700 & & \\
\hline & & Supervisor & 1700 & & \\
\hline & & Plumber & 1700 & & \\
\hline & & Fabricator & 1700 & & \\
\hline & & Denter & 1700 & & \\
\hline & & Mechanics & 1700 & & \\
\hline & & Driver & 1700 & & \\
\hline & & Crane Operator & 1700 & & \\
\hline & & Welder & 1700 & & \\
\hline & & Bar Bender & 1700 & & \\
\hline & & A/C Technician & 1700 & & \\
\hline
\end{tabular}

Source: e Migrate, Ministry of External Affairs, Government of India 
Table 9 Table remittance inflows to India (in USD million)

\begin{tabular}{lll}
\hline Year & Inflows from Saudi Arabia & Total inflows \\
\hline 2010 & 6461 & 53,480 \\
2011 & 7616 & $(12.08)$ \\
& & 62,499 \\
2012 & 8382 & $(12.19)$ \\
& & 68,821 \\
2013 & 10,771 & $(12.18)$ \\
& & 69,970 \\
2014 & 10,737 & $(15.39)$ \\
& & 70,389 \\
2015 & 11,253 & $(15.25)$ \\
& & 68,910 \\
2016 & 10,225 & $(16.33)$ \\
& & 62,744 \\
2017 & 11,239 & $(16.30)$ \\
& & 68,967 \\
& & $(16.30)$ \\
& & 78,790 \\
& & $(14.81)$ \\
& & 83,131 \\
\hline
\end{tabular}

Source: World Bank Remittance Data

Figures in the parentheses indicate the proportion of remittance inflows from Saudi Arabia to total inflows

\section{References}

Abella, Manolo I. 2020. Labour Migration Policy Dilemmas in the Wake of COVID-19. International Migration 58(4): 255-258.

Bouhga-Hagbe, Jacques. 2006. Altruism and Workers' Remittances: Evidence from Selected Countries in the Middle East and Central Asia. IMF Working Paper. WP/06/130. International Monetary Fund.

De Bel-Air, Francoise. 2018. Demography, Migration and Labour Market in Saudi Arabia. Gulf Labour Markets and Migration. European University Institute and Gulf Research Center.

Centre for Monitoring Indian Economy (CMIE). 2020. Unemployment Rate in India. July. CMIE.

International Labour Organisation (ILO). 2020. COVID-19: Labour Market Impacts and Policy Responses in Arab States. ILO.

International Monetary Fund. 2020. World Economic Outlook: Chapter 1: The Great Lockdown. IMF.

Nereim, Vivian. 2020. Expat Departure to Benefit Saudi Arabia's Unemployed. Bloomberg. June 15.

Sasikumar, S.K. 2014. Maximising Developmental Outcomes of International Labour Migration and Remittances: The South Asian-Gulf Experience. Labour \& Development 21(2): 30-57.

Sasikumar, S. K., and Seeta Sharma. 2016. Minimum Referral Wages for International Migrant Workers from India: An Assessment. ILO.

United Nations Department of Economic and Social Affairs (UNDESA). 2019. International Migrant Stock: By Destination and Origin. UNDESA.

World Bank - KNOMAD. 2020a. Covid-19 Crisis Through a Migration Lens, Migration and Development Brief 32. World Bank. 
World Bank. 2020b. How Transparency Can Help the Middle East and North Africa, MENA Economic Update April. World Bank.

Publisher's Note Springer Nature remains neutral with regard to jurisdictional claims in published maps and institutional affiliations. 